\title{
Geodynamic implications of moving Indian Ocean hotspots
}

\author{
Craig O’Neill ${ }^{\mathrm{a}, *}$, Dietmar Müller ${ }^{\mathrm{a}}$, Bernhard Steinberger ${ }^{\mathrm{b}}$ \\ a University of Sydney, School of Geosciences, Building F05, Sydney, NSW 2006, Australia \\ b IFREE, JAMSTEC, 2-25 Natsushima-cho, Yokosuka 237-0061 Japan
}

Received 6 January 2003; received in revised form 12 May 2003; accepted 3 June 2003

\begin{abstract}
The reconstructed positions of many of the Indian Ocean intraplate volcanic features are inconsistent with the present positions of the hotspots to which they have been ascribed. The discrepancy can be explained by the past motion of the hotspots themselves, and in the errors introduced in an absolute plate model based on fixed hotspots. Previous models for the motion of hotspots in the Indian Ocean (e.g. [Steinberger and O'Connell, in: The History and Dynamics of Global Plate Motions, 2000, pp. 377-398, and Geophys. J. Int. 132 (1998) 412-434; Antretter et al., Earth Planet. Sci. Lett. 203 (2002) 635-650]) have had success in matching paleolatitudes of the Kerguelen hotspot, but not the Marion or Reunion hotspots. We calculate the motion of the Indian Ocean hotspots using a method described in Steinberger and O'Connell (op. cit.), employing a plate motion model revised using identification of Mesozoic magnetic anomalies in the Enderby Basin [Gaina et al., in: The Evolution and Dynamics of the Australian Plate, in press]. We find a motion of $\sim 7^{\circ}$ south for the Kerguelen plume, similar to previous models [Antretter et al., op. cit.]. This motion alleviates the discrepancies in the position of the Kerguelen plume and its purported involvement in the formation of the Ninetyeast Ridge, Rajmahal Traps, Bunbury basalts and assorted volcanics of the Western Australian margin. We find a motion of $5^{\circ}$ north and $7^{\circ}$ south for the Reunion and Marion plumes, respectively. The motion of the Reunion hotspot is consistent with paleolatitude estimates. The apparent fixity of the Marion hotspot [Torsvik et al., Earth Planet. Sci. Lett. 164 (1998) 221-232] is not well-constrained, but may be due to the combination of hotspot motion and true polar wander acting in opposing directions. We present revised absolute finite rotations for the Indian plate for the last $65 \mathrm{Ma}$ based on the motion of these hotspots, which place India farther north in the past than for fixed hotspot models.
\end{abstract}

(C) 2003 Elsevier B.V. All rights reserved.

Keywords: hotspot; Indian Ocean; intraplate volcanics; plate reconstruction; paleolatitude; plume

\section{Introduction}

Many of the intraplate volcanic features of the

* Corresponding author. Tel.: +61-2-9351-3682;

Fax: +61-2-9351-0184.

E-mail address: craig@es.usyd.edu.au (C. O’Neill).

Supplementary data associated with this article can be found at doi:10.1016/S0012-821X(03)00368-6 Indian Ocean are attributed to known hotspots. However, the reconstructed positions of many of these features are inconsistent with the presentday positions of these hotspots. For example, the involvement of the Kerguelen plume with the formation of the Ninetyeast Ridge (36-84 
Ma [6,7]), the Rajmahal Traps (117 Ma [8,9]) and the separation of the Elan Bank microcontinent $(<124 \mathrm{Ma}[4,10])$ requires that the plume was farther north at those times. Royer et al. [11] found that the misfit between the Kerguelen hotspot and Ninetyeast Ridge is minimized by allowing for a southward motion of the hotspot of $\sim 10^{\circ}$ between 84 and $36 \mathrm{Ma}$. Paleolatitudes determined from paleomagnetic data and models of hotspot motion [3] both suggest that the Kerguelen plume was $\sim 10^{\circ}$ farther north at $110 \mathrm{Ma}$. The Kerguelen hotspot has also been implicated in the formation of the Bunbury basalts (123-132 Ma [12,13]) and the volcanics of the Western Australian margin (136-96 Ma [14]); however, its involvement is difficult to reconcile with its presentday position.

The Reunion plume shows a northward motion in the paleomagnetic reference frame of $\sim 5^{\circ}$, which Vandamme and Courtillot [15] attribute to true polar wander (TPW). The Marion plume shows no significant paleolatitudinal motion, which Torsvik et al. [5] argue as evidence that the plume has remained stationary over the last $83 \mathrm{Ma}$. However, this fixity leads to problems with the reconstructed position of the Madagascan volcanics at their respective ages, and with paleolatitudes expected from TPW calculations.

Significant improvements have also been made in understanding the relative plate motions in the Indian Ocean. Considerable distributed deformation has occurred between the Indian and Australian plates, resulting in their separation into two separate tectonic blocks [16]. More recently, the identification of Mesozoic anomalies in the Enderby Basin [4] implies considerable recurrent right-lateral/left-lateral motion between India and Madagascar prior to their breakup. The improvements in the relative plate motion models, and the constraints provided by their uncertainties, have highlighted the inconsistencies between the present positions of hotspots, and the reconstructed positions of the volcanics ascribed to them. The problem is two-fold. First, the motion of the Indian Ocean hotspots themselves can, to a large degree, minimize the difference in the positions of the hotspots and their reconstructed volcanic trails. However, the reconstructed positions of the hotspot volcanics themselves are based on an absolute plate motion model assuming fixed hotspots.

The purpose of this paper is to resolve the inconsistencies in the paleo-positions of the Indian Ocean hotspots and their volcanic products. We review the hotspot-related volcanic features of the Indian Ocean which have traditionally been ascribed to major hotspots. The motion of these hotspots is calculated using a method outlined in Steinberger and O'Connell [1,2]. We use a significantly revised Indian Ocean plate model [4], together with a global tomography model, to calculate the mantle flow field through time and the advection of plumes in this flow field. A revised absolute plate model of the Indian Ocean is presented based on the calculated motion of these hotspots.

\section{Hotspots and volcanic features of the Indian Ocean}

The Indian Ocean consists of portions of three major tectonic plates, the Indo-Australian, the Antarctic, and the African. The oceanic lithosphere has been formed over the last 160 Ma by seafloor spreading along the Central Indian, Southwest Indian and Southeast Indian ridges (Fig. 1). There are four important areas of localized volcanism not related to these plate margins, namely the Reunion, Marion, Crozet and Kerguelen hotspots.

The plume head of the extant Reunion hotspot formed the Deccan Traps around the time of the KT boundary, about 65-66 Ma [17,18]. Their present surface area is over $500000 \mathrm{~km}^{2}$, covering most of western India $[17,18]$. Subsequent to this, the plume formed the Laccadives-Maldives-Chagos ridge, and its conjugate on the African plate, the Seychelles-Mascarene ridge, Nazareth Bank and the island of Mauritius. The two ridges are separated by the Carlsberg-Central Indian Ridge system. The present position of the hotspot is at $21.1^{\circ} \mathrm{S}$ and $55.5^{\circ} \mathrm{E}$ [17]. Paleolatitudes obtained from lava flows cored at ODP drill sites 706, 707 and 715 [15] suggest that the Reunion hotspot drifted north between 55 and $35 \mathrm{Ma}$ by about $5^{\circ}$. 


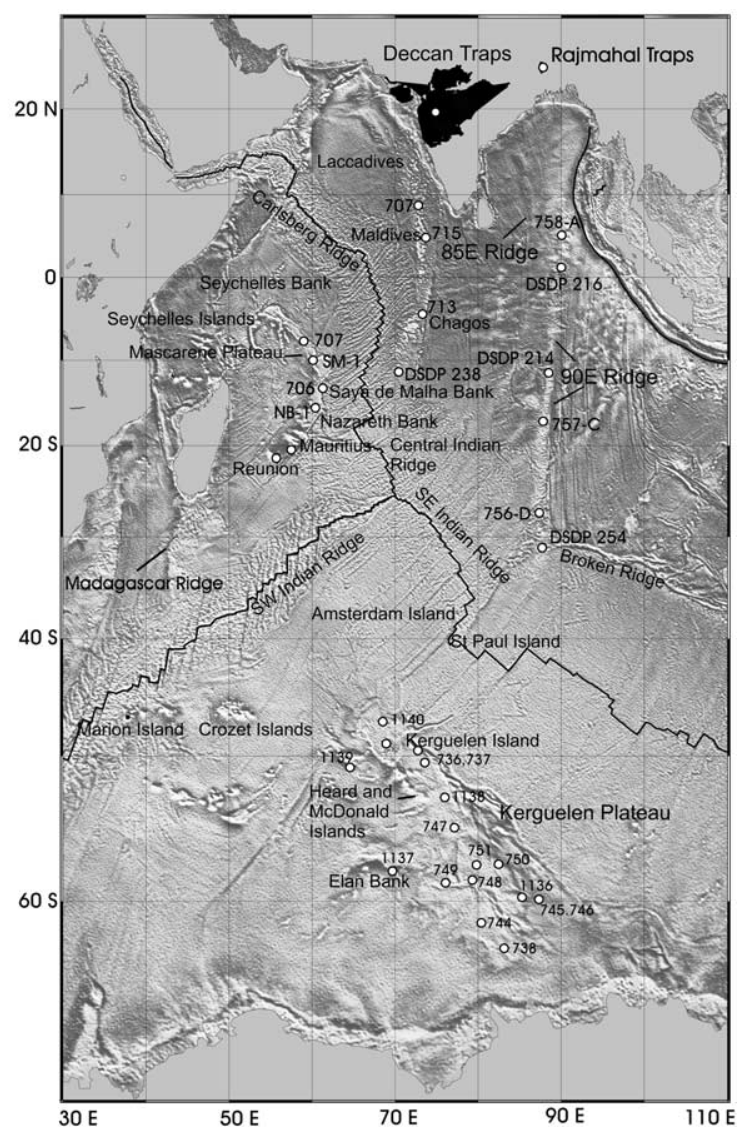

Fig. 1. Satellite gravity map (from [69]) of the major volcanic features of the Indian Ocean. Major oceanic plate boundaries shown as solid black line. Unfilled circles indicate sample locations together with their radiometrically determined ages, from ODP Legs 115 (Reunion track, holes 706, 707 and 715), industry wells (SM-1 and NB-1), ODP Legs 119, 120 (Kerguelen Plateau, holes 747-749), 121 (Ninetyeast Ridge, holes 756-758) and 183 (Kerguelen Plateau, holes 1138 and 1140) $[3,15,17,38,42,55,70]$.

The Marion hotspot is potentially one of the most ancient extant hotspots (over 183-184 Ma), and has been purported to have formed the Karoo flood basalts in Southern Africa (e.g. [7]). It may have been responsible for much of the Cretaceous flood basalt in Madagascar [19,20]. Southeast Madagascar superposed the Marion plume at $90 \mathrm{Ma}$, and paleolatitudes from the proposed site of the plume give a value of $45.3+5.3 /-4.7^{\circ} \mathrm{S}$, not significantly different from the observed present position of $46^{\circ} \mathrm{S}, 37.8^{\circ} \mathrm{E}$. This has been interpreted as evidence that the Marion plume has moved little with respect to the geomagnetic pole in the last $90 \mathrm{Ma}$. Subsequent to the Madagascar volcanism, the plume created the Madagascar Ridge [19,21] between southern Madagascar and Marion Island.

The Kerguelen hotspot is thought to underlie the Kerguelen Archipelago, at $49^{\circ} \mathrm{S}, 69.5^{\circ} \mathrm{N}$ [10], on the north end of the Kerguelen. The plateau, about $2300 \mathrm{~km}$ long, is divided into three broad domains. The north Kerguelen plateau contains the only three subaerial features of the region; Kerguelen, Heard and MacDonald Islands. The present center of volcanism is found in the North Kerguelen Plateau, on Heard and MacDonald Islands [22]. There exists a progression in ages over the plateau, with the northernmost parts recently dated between 34 and $68 \mathrm{Ma}$ (sites 1140 and 1139, respectively [23]). Duncan [23] has recently dated the central plateau (site 1138) at 100.4 $\pm 0.7 \mathrm{Ma}$. The southern plateau is generally deeper, and has been dated at 118-119 Ma (site 1136 [23]), and 110-112 Ma (sites 749 and 750, recently reanalyzed in [24]). The Elan Bank microcontinent is found on the west margin of the plateau, and has been postulated to be a microcontinental sliver formed no earlier than $124 \mathrm{Ma}$ when the Indian subcontinent superposed the Kerguelen plume [7]. The conjugate to the Kerguelen plateau on the Indo-Australian plate is Broken Ridge ( $95 \mathrm{Ma}$ $[23,25])$, and the two are separated by the Southeast Indian ridge.

An age progression has been inferred for the Ninetyeast Ridge on the basis of biostratigraphic and radiometric data obtained from ODP Leg 121 [6]. This has been proposed to be due to the passage of the Indo-Australian plate over the Kerguelen plume [5]. The offset of magnetic anomalies across the ridge (e.g. [26]) suggests transform motion has occurred across it, and the ridge may have been a pre-existing structural feature, along which the hotspot volcanism was focused.

The Rajmahal Traps have traditionally been assumed to represent volcanism associated with the Kerguelen plume head [7,9]. This assumption has not gone unchallenged (e.g. [27-29]). The major problem for the Kerguelen plume source theory is that plate reconstruction models based on a fixed hotspot reference frame [28] place the 
Rajmahal Traps around $1000 \mathrm{~km}$ north of the Kerguelen plume at the time of their eruption $117 \mathrm{Ma}$. The uncertainties in the relative plate motion model are not large enough to account for such a discrepancy. In response to this, Müller et al. [28] suggested that a putative plume located at the Conrad Rise $\left(\sim 51^{\circ} \mathrm{E}, 53^{\circ} \mathrm{S}\right)$ may have formed the Rajmahal Traps. Similarly, Curray and Munasinghe [29] proposed that the Crozet hotspot may have formed the Rajmahal Traps. Both hotspots have been proposed to have formed the $85^{\circ} \mathrm{E}$ ridge subsequent to the Rajmahal volcanism.

The Rajmahal Traps have been erupted through continental lithosphere, and the original plume melt has been significantly contaminated. As a result, geochemistry has been used to support $[8,30,31]$ and refute $[9,27]$ the suggestion that the Kerguelen plume was responsible for the Rajmahal volcanism. Little geochemical evidence is available for the $85^{\circ} \mathrm{E}$ ridge to test its genetic relation to the Rajmahal Traps [27]. A similar situation exists for the Conrad Rise hotspot. Isotope systematics from the Crozet Archipelago [27] show no overlap with the Rajmahal Traps. Similarly, $\mathrm{Pb}$ isotopes from the Afanasy-Nikiti ( $\sim 80$ Ma) seamount, supposedly formed by the Crozet hotspot subsequent to the $85^{\circ} \mathrm{E}$ ridge, are unlike the Rajmahal Traps [27]. Indeed, it is not even certain this seamount is related to the Crozet hotspot [27].

Alternatively, the Rajmahal Traps may represent volcanic activity instigated by the Kerguelen plume head, but at a distance from the actual location of the plume. Given that the radius of influence of other large igneous provinces (LIPs) can exceed $1000 \mathrm{~km}$ [32], it is certainly possible that a large plume head can contribute to distributed volcanics over $1000 \mathrm{~km}$ scales. Lamprophyre dykes on the conjugate Indian-Antarctic margins ( 114-115 [24]) have been attributed to heating due to the Kerguelen plume, suggesting an area of influence of $\sim 2000 \mathrm{~km}$ [24]. Similarly, attributing the Bunbury basalts to the Kerguelen plume [13, 33] suggests involvement over a large $(\sim 1000$ $\mathrm{km}$ ) area. No motion of the Kerguelen plume would be required in this case to explain its contribution to the Rajmahal Traps.
Recent drilling of the Elan Bank (ODP Leg $183,[10])$ found clasts of garnet-biotite gneiss in a fluvial conglomerate. This has been interpreted as unequivocal evidence of the continental origin of the Elan Bank sediments. More recently, Gaina et al. [4] have proposed that the Elan Bank is a microcontinental sliver that detached from the Indian continent during a ridge jump after $124 \mathrm{Ma}$, reportedly caused by the Kerguelen plume. Basaltic flows obtained from ODP site 1137 have been dated at 107-109 Ma [23]; this may be related to the rifting of Elan Bank, or to later plume activity. In either case, assuming a stationary plume requires a ridge jump away from the position of the plume, into a continental area. More plausibly, the ridge jumped to the actual position of the plume, an area of pre-weakened lithosphere [4]. This model requires the plume to be around $10^{\circ}$ north of its present position at $124 \mathrm{Ma}$.

Current volcanism in the Comores Archipelago occurs on Grand Comore at La Grille and $\mathrm{Ka}$ raltha; the latter is thought to be younger [34]. There exists an age progression to the Islands, thought to be due to the passage of the Somali plate over a hotspot [35]. The Amsterdam-St. Paul hotspot lies on the Southeast Indian Ridge, and current volcanism occurs on both Amsterdam and St. Paul Islands, as well as the Boomerang seamount [36]. It has been suggested that the Amsterdam-St. Paul hotspot may have been involved in the Ninetyeast Ridge volcanism [36,37] and the volcanics of the Western Australian margin [14].

\subsection{Constraints on hotspot motion}

The history of the Indian Ocean hotspots has received considerable attention in the literature, and so a large number of age and paleomagnetic data, of varying quality, exist to constrain their evolution. The data used to constrain our hotspot motion models are shown in Table 1. Our single point for the Marion plume is from southwest Madagascar, documented by Torsvik et al. [5]. They present a concordant plateau age of $83.6 \pm$ 1.6 , and a mean Late Cretaceous pole which results in a paleolatitude of $45.4^{\circ} \mathrm{S}_{-4.3}^{+5.8}$. Duncan and Hargraves [38] have reported concordant ages for the Reunion track from ODP Leg 115 (sites 706, 
707 and 715); we have adopted the mean isochron ages. Vandamme and Courtillot [15] present paleomagnetic results for these sites. While the secular variation appears to be averaged at site 706 , tectonic tilting appears to have affected the basement, and the value presented here is for the (lessaffected) sediment. Sites 707 and 715 are apparently unaffected by tilt; however, it is suspected that secular variation was not averaged out at site 707 [15]. A review of published ages for the Deccan Traps, plus new results, is found in Hofmann et al. [39]. They find that many earlier dates were affected by ${ }^{39} \mathrm{Ar}$ recoil, and tend to overestimate the age of the Traps [39]. They give a new mean age of $65.5 \mathrm{Ma}$. Deccan paleomagnetic results are from Courtillot et al. [18] and are reviewed in Vandamme et al. [40].

ODP Leg 120 (sites 747-749) sampled the Kerguelen Plateau. Site 749 has an apparently reliable age [41] and paleolatitude [42]. Site 748 sampled a sill and its relationship to the Kerguelen plume is not clear, and site 747 has a discordant age estimate [23]. Secular variation is not averaged at site 748 , and site 747 appears to be affected by tilting

Table 1

Summary of age and paleolatitude data used in Fig. 4

\begin{tabular}{lcccccc}
\hline Site & Age & $\pm \sigma$ & $\begin{array}{l}\text { Paleo- } \\
\text { latitude }\end{array}$ & & & Reference \\
\hline $\begin{array}{l}\text { Marion } \\
\text { Madagascar }\end{array}$ & 83.6 & 1.6 & -45.3 & +5.3 & -4.7 & {$[5]$} \\
$\begin{array}{l}\text { Reunion } \\
\text { Deccan }\end{array}$ & 65.5 & 1.0 & -26.4 & +3.9 & -3.6 & {$[18,39]$} \\
Traps & & & & & & \\
707 & 64.1 & 1.1 & -25.2 & +4.3 & -4.2 & {$[15,38]$} \\
715 & 57.5 & 2.5 & -25.0 & +5.8 & -5.0 & {$[15,38]$} \\
706 & 32.9 & 0.7 & -21.7 & +2.9 & -2.9 & {$[15,38]$} \\
Kerguelen & & & & & & \\
Rajmahal & 118.2 & 0.3 & -47.0 & +3.2 & -3.4 & {$[24,44]$} \\
Traps & & & & & & \\
749 & 109.9 & 1.0 & -43.0 & +4.5 & -5.1 & {$[41,42]$} \\
748 & 100 & - & -45.0 & - & - & {$[41,42]$} \\
1138 & 100.4 & 0.7 & -43.6 & +5.7 & -4.2 & {$[3,23]$} \\
747 & 85 & - & -32.0 & - & - & {$[41,42]$} \\
758 & 81.8 & 2.6 & -45.8 & +5.4 & -3.7 & {$[6,43]$} \\
757 & 57.9 & 1.6 & -47.5 & - & - & {$[6,43]$} \\
756 & 43.2 & 0.5 & -43.4 & +4.9 & -4.9 & {$[6,43]$} \\
1140 & 34.3 & 0.6 & -35.8 & +6.9 & -7.2 & {$[3,23]$} \\
\hline
\end{tabular}

For discussion, see text.
[42]. Hence sites 747 and 748 should be treated as suspect. ODP Leg 121 (sites 756-758) sampled the Ninetyeast Ridge, and all these sites appear to be affected by minor alteration [6]. Sites 756 and 758 show concordant ages, and we have adopted the mean plateau age and weighted mean site age, respectively [6]. The ages of site 757 are not quite concordant [6]. Klootwijk et al. [43] present paleolatitudes for sites 756-758. They observe aberrant inclinations for site 757 , possibly related to a tectonic disturbance in the basement caused by a ridge jump. Site 758 shows possible evidence for magnetic overprint [43]. The Kerguelen Plateau was revisited in ODP Leg 183, and ages for sites 1138 and 1140 are from Duncan [23]. While neither site shows evidence for tilting, paleosecular variation at site 1140 may not have been averaged out [3]. The Rajmahal Traps have been recently re-dated by Coffin et al. [24], and paleomagnetic results are documented in Klootwijk [44].

\section{Model description}

We use a method for calculating the motion of hotspots previously described in detail in Steinberger and O'Connell $[1,2,45]$. The flow field of the mantle is calculated for times in the past using a spectral method of Hager and O'Connell [46, 47]. This uses a spherical harmonic expansion of surface plate velocities and internal density heterogeneities at each depth level. The flow field is calculated for each spherical harmonic degree and order.

Internal density heterogeneities are determined from global tomographic models. In this study we used Steve Grand's model (obtained from anonymous ftp, 2001, similar to [48]) and the Harvard S12WM13 model [49]. To convert from seismic velocities to density heterogeneities, a conversion factor $(\delta \rho / \rho) /\left(\delta v_{\mathrm{s}} / v_{\mathrm{s}}\right)$ of 0.2 was used for S12WM13, and 0.4 for Grand's model to compensate for its lower amplitudes.

We used the preferred viscosity structure of Steinberger and O'Connell [45], which is based on geoid and postglacial rebound constraints. The boundary conditions are a stress-free coremantle boundary, and revised surface plate veloc- 
ities (discussed in more detail in the next section). The approximations made in this model, such as neglecting thermal effects, are discussed in more detail in Steinberger and O'Connell [2]. They are found to be valid for times less than $\sim 68 \mathrm{Ma}$. For times older than this, the density anomalies were left constant.

Our modeling of the motion of plumes is based on the conception of plumes as initially consisting of a large plume head, followed by a narrow conduit (cf. [1,50]). The initial plume head rises much faster than the narrow conduit [1,2,50], and on reaching the surface has been associated with the formation of LIPs. As our starting point, we model the hotspot as the uppermost point of an initially vertical plume conduit at a time equal to the assumed age of the hotspot (i.e. age of associated flood basalts), extending from the base of the mantle to the surface. In this sense the plumes are the 'primary' plumes of Courtillot et al. [51]; we have not considered plumes of shallower origin. The motion of the plume subsequent to this consists of components due to the advecting flow field and its buoyant rising. Other values of our models are similar to the preferred model of Steinberger and O'Connell [1,2], which contains further details of modeling assumptions.

As a surface boundary condition to our mantle flow model, we used a revised model for plate motions in the Indian Ocean based on fixed hotspots, previously described in Gaina et al. [4]. This model is based on the identification of Mesozoic magnetic anomalies in the Enderby Basin, and implies a large recurrent strike-slip motion of India and Madagascar, prior to the separation of India from Gondwana [4]. The surface motion of plates has a first-order effect on the mid-mantle flow field and the motion of hotspots in the flow field. This improved model of Indian Ocean plate motion will result in a significantly different calculated hotspot motion, compared with previous models that do not include Mesozoic spreading in the Enderby Basin.

\section{Motion of the Indian Ocean hotspots}

Fig. 2 shows the calculated motion of the Ker- guelen plume for a number of different plate reconstructions, tomographic models, and seismic velocity conversion factors. Fig. 2, top, illustrates the calculated motion for the Harvard S12WM13 tomography model [49], with a seismic velocity conversion factor of 0.2 . The plate model is an older model, described in [52] and [53]. This is a similar model to those presented by Steinberger and O'Connell [1,2]. Fig. 2, middle, illustrates the motion of the Kerguelen plume for the Grand tomography model [48], with seismic velocity conversion factors of 0.4 . Fig. 2, bottom, illustrates the motion of the Kerguelen plume for the S12WM13 model, with a conversion factor of 0.2 , but with the revised plate model of Gaina et al. [4]. A detailed treatment of the dependence of the models with different modeling assumptions can be found in Antretter et al. [3] and Steinberger [54]. Despite the differences in calculated motion between the models, a number of features are remarkably consistent between them. Most notably, there is a $5-10^{\circ}$ southward drift of the Kerguelen plume for every model for the last $117 \mathrm{Ma}$. This motion is consistent with paleomagnetic results $[3,42,55]$, which independently suggest a $5-10^{\circ}$ southward drift of the Kerguelen plume since the formation of the Kerguelen plateau.

Fig. 3 shows the positions and calculated motions of major and purported Indian Ocean hotspots through their lifetimes, based upon the S12WM13 tomography model, with a conversion factor of 0.2. The plate model is from Gaina et al. [4]. The motion of the Marion plume is shown only for the last $90 \mathrm{Ma}$, since it superposed Madagascar. The Reunion plume is plotted since the formation of the Deccan Traps at $65 \mathrm{Ma}$. The Rajmahal Traps were formed at $\sim 117 \mathrm{Ma}$. Since it has been variously suggested that the Crozet, Kerguelen and Conrad Rise hotspots all formed the Rajmahal Traps, the motion of all of these hotspots has been calculated for the last 117 Ma. The St. Paul and Comores hotspots have been calculated for 130 and $60 \mathrm{Ma}$, respectively. The calculated slant of the Kerguelen and Reunion hotspots are also shown. The resulting tilt is of the order of $40^{\circ}$ for the Kerguelen plume, which is less than the instability threshold of 
Whitehead [56]. However, large variations in midmantle flow due to the passage of the Indian plate may cause strong shearing of the conduits, especially if the conduit is already tilted at the time of LIP emplacement due to the finite rising time of the plume head.

Steinberger and O'Connell [1,2] have suggested that the motion of hotspots, as seen on the surface, is largely related to plate return flow at midmantle depths. To illustrate this effect, we have also shown the present-day flow field at $670 \mathrm{~km}$ in Fig. 3. The arrows indicate the direction of flow, with lengths corresponding to the total displacement that would result from $68 \mathrm{Ma}$ of constant flow. The field varies back though time due to changes in plate velocities and, subsequently, mantle return flow. Nonetheless, the present field provides an illustration of the cause of the observed differential motion between Indian Ocean hotspots. The motion is not consistent with previous studies (e.g. [7,28,57,58]) that concluded that the Indo-Atlantic hotspot group has moved coherently in the past.

\subsection{Reunion}

Previous numerical models of the Reunion hotspot $[1,2,45]$ have consistently predicted a sharp northward drift of the Reunion plume immediately after the Deccan volcanism, followed by a southward drift of the plume for the last $50 \mathrm{Ma}$. These calculations were based on the plate rotations described in [52] and [53]. Such motion is not consistent with paleolatitude estimates [15], which suggest a northward drift of Reunion of around $5^{\circ}$ from 58 to $36 \mathrm{Ma}$. These paleolatitudes have previously been shown to be consistent with some TPW curves (e.g. [14,59]; see Fig. 4, bottom). However, they are not consistent with estimates of paleolatitude based on other TPW curves [60].

In contrast, the calculated motion shown in Fig. 3 is based on the plate model of Gaina et al. [4]. The east-northeast drift of the Reunion plume is a consistent feature of all our models using these plate motions. A comparison to paleolatitude estimates of the Reunion plume (Fig. 4) shows good agreement. Unfortunately, the calcu-
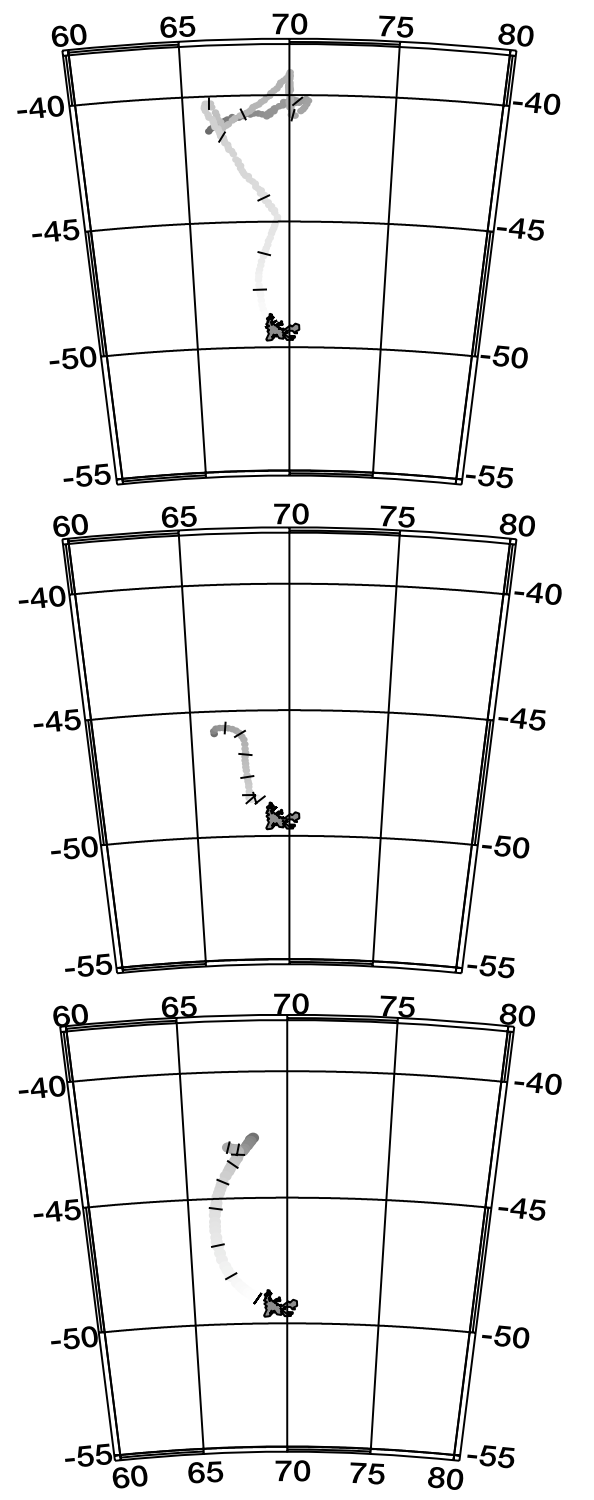

\section{OMa}

$117 \mathrm{Ma}$

Fig. 2. Calculated motion of the Kerguelen hotspot. (Top) For the S12WM13 model [49], conversion factor 0.2, and old plate model [52,53]; (middle) Grand model [48], conversion factor 0.4; (bottom) S12WM13 model [49], conversion factor 0.2 , new plate model [4]. Tickmarks represent 10 Myr intervals; coastline of Kerguelen Island shown. 
lated longitudinal variation presently remains poorly constrained, though it is within the longitudinal range of the Deccan Traps.

\subsection{Marion}

The Marion plume exhibits a southward drift of around $5-10^{\circ}$ in every model. Steinberger and O'Connell [1,2] also calculated this southward drift. However, Torsvik et al. [5] argue that this motion is not consistent with paleomagnetic constraints from Madagascar, and that the fixed hot- spot model provides a better fit within the resolution of the paleomagnetic data.

There may be a number of reasons for this discrepancy. Firstly, though there is a documented age progression to the volcanics, from $91.6 \pm 0.3 \mathrm{Ma}$ in the northeast to $83.6 \pm 1.6$ for the southwest [5], the position of the Marion plume at these times is not well-constrained. Melt propagating through the continental lithosphere can erupt quite distally from the sub-lithospheric plume source [39]. The latitudes spanned by the volcanics (around $8^{\circ}$ ), together with the

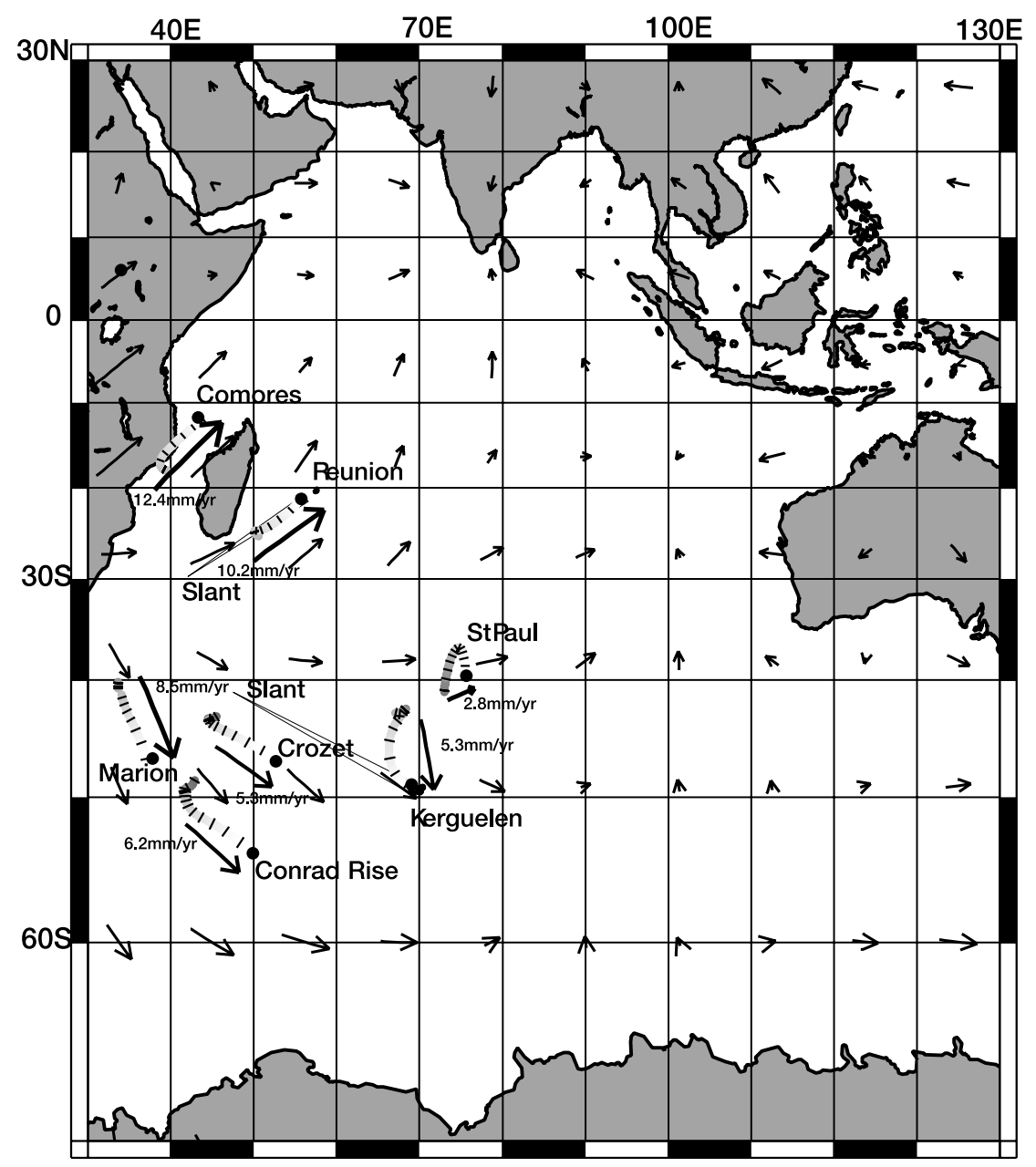

Fig. 3. Calculated motion of the Indian Ocean hotspots since the estimated time of their initial eruption (grayscale from $120 \mathrm{Ma}$ (black) to $0 \mathrm{Ma}$ (white, as in Fig. 2); tickmarks every $10 \mathrm{Myr}$ ). Average velocities of hotspots over their lifetimes labeled, directions shown as thick arrows. Based on the S12WM13 model [49], conversion factor 0.2, new plate model [4]. Also shown is the present-day flow field at $670 \mathrm{~km}$ (arrow scale $1^{\circ}=1^{\circ} / 40 \mathrm{Myr}$ ), and the calculated present mean slant of the Reunion and Kerguelen plumes (dot represents position of plume on the surface, vertices represent the position of the plume at the CMB). 
contemporaneous rifting of India and Madagascar, make it difficult to constrain the plume position with any degree of confidence. This range of latitudes also makes it difficult to assign a combined Madagascan paleomagnetic pole for the period spanned.

Furthermore, fixed hotspot reconstructions [28] place southeast Madagascar over a stationary Marion plume at $90 \mathrm{Ma}$. The volcanics of southeast Madagascar have been dated at $83.6 \pm 1.6$, not $90 \mathrm{Ma}$, and give a paleolatitude of $47^{\circ} \mathrm{S}$ [5]. However, if the Marion plume was further north at $83 \mathrm{Ma}$, it would have superposed southeast Madagascar; this is more consistent with the ages of the youngest volcanics.

Interestingly, older TPW curves [59] give negative latitude offsets at $83 \mathrm{Ma}$ for the Marion plume. So the combined effects of hotspot motion and older TPW curves would cancel, and result in little paleolatitude variation. While the recent TPW curve of Besse and Courtillot [61] gives negative latitudinal offsets for the Marion plume for younger times, there is little offset at $83 \mathrm{Ma}$ (Fig. 4, bottom).

One explanation for these observations may be that the Marion plume has not moved, and that it was beneath southwest Madagascar at $83 \mathrm{Ma}$, and that the paleolatitudes obtained for that time reflect this fixity, and the offset expected from TPW. This does not reconcile the problems with reconstructed positions of Madagascar with respect to the present position of the Marion hotspot, or address the predictions of dynamical modeling. Alternatively, the plume may have been further north than the models presented here predict, and beneath southwest Madagascar at $83 \mathrm{Ma}$. This is consistent with absolute plate motion models. This hypothesis predicts minimal paleolatitude variations when combined with older [59] TPW curves, as observed, but is not consistent with paleolatitude estimates including the effects of the latest Besse and Courtillot [61] TPW curves.

\subsection{Kerguelen, Crozet, Conrad Rise and the Rajmahal Traps}

Calculated motions for the Kerguelen and the putative Crozet and Conrad Rise plumes are shown in Fig. 3. The southward motion of the Kerguelen plume is a feature of all our models (see Fig. 2), and this motion is consistent with paleolatitude estimates from drillsites on the Kerguelen Plateau $[42,55]$. As a consequence of their
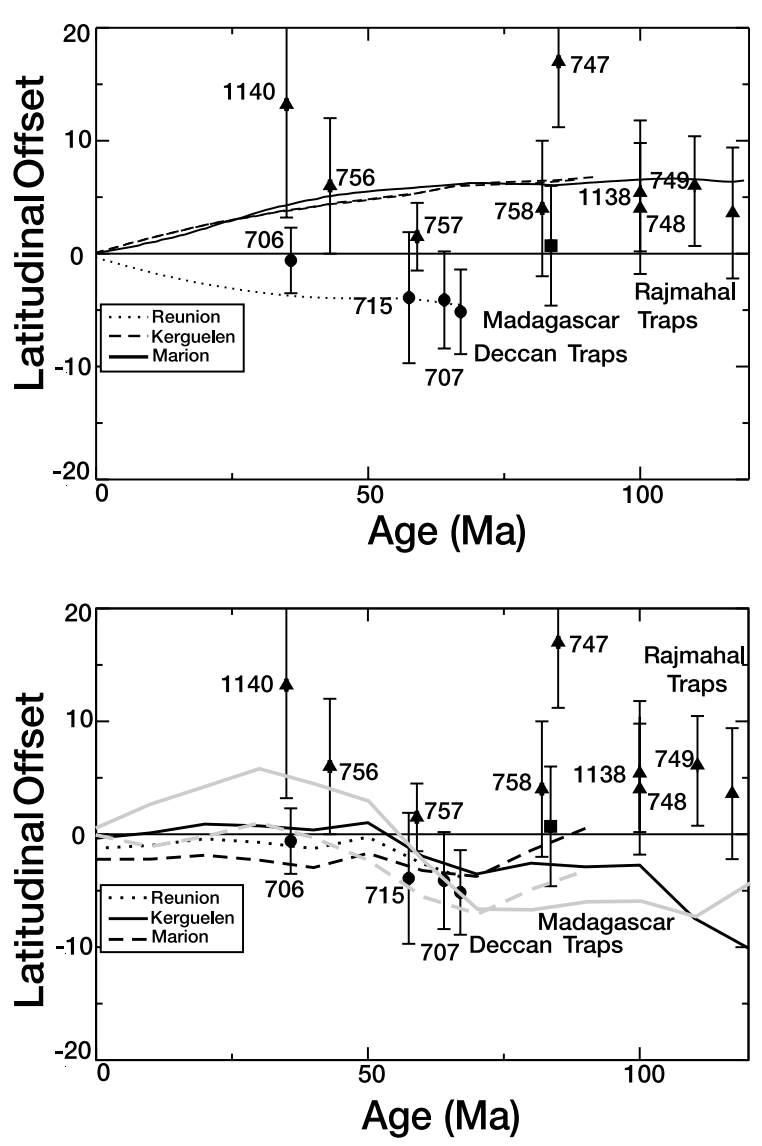

Fig. 4. (Top) Calculated latitudinal offset from present-day positions for the Kerguelen, Reunion and Marion hotspots, based on the hotspot motion shown in Fig. 3. Marion hotspot only shown for times less than $90 \mathrm{Ma}$. Also shown are paleolatitude estimates from Table 1, from the Deccan Traps [17], Madagascar [5], the Rajmahal Traps [44], and from ODP Legs 115 (Reunion track, holes 706, 707 and 715), 119, 120 (Kerguelen Plateau, holes 747-749), 121 (Ninetyeast Ridge, holes 756-758) and 183 (Kerguelen Plateau, holes 1138 and 1140) $[3,15,17,42,55,70]$. Paleolatitude uncertainties not published (cf. Table 1) have been estimated from inclination data. (Bottom) Calculated latitudinal offset for the Kerguelen, Reunion and Marion hotspots, based on the TPW curves of Besse and Courtillot (1991 [37], gray, and 2002 [61], black). Assumes fixed hotspots. Data as in Fig. 4, top. 
proximity to the Kerguelen plume, the Crozet and Conrad Rise hotspots also show a similar amount of motion. In both cases, the plumes have drifted in a southeasterly direction (over $10^{\circ}$ ) in the last $90 \mathrm{Ma}$. This has significant implications for their role in the formation of the Rajmahal Traps.

The reconstructions shown in Fig. 5 are based on a fixed African hotspot model. The positions of the hotspots are those calculated at the specified time, and are based on the motion shown in Fig. 3. A key feature to note is that the latitudinal discrepancy previously noted between the Rajmahal Traps and the Kerguelen plume is obviated at $90 \mathrm{Ma}$, although at $120 \mathrm{Ma}$ there is still a small offset. One explanation for this may be the uncertainty in our calculated hotspot motion. However, the required motion to fit the Rajmahal Traps at $120 \mathrm{Ma}$ is then around $15^{\circ}$, which exceeds all paleolatitude estimates of the Kerguelen plume $[42,55]$. Our preferred explanation is the uncertainty in the absolute reference frame during the Cretaceous. For these times, absolute plate motions are generally constrained by only a few hotspots, namely, Tristan de Cunha, New England, and Meteor [28,62]. However, there is good evidence that at least some of these hotspots moved relative to the mantle reference frame during the Cretaceous [62]. For example, the estimated motion of the New England hotspot has been estimated to have been $11^{\circ}$ in the midCretaceous [62]. The magnitude of this motion more than embodies the discrepancies in our model, and highlights the need to incorporate the motion of hotspots in absolute plate motion models.

The Crozet and Conrad Rise hotspots both show a large longitudinal offset from the Rajmahal Traps at the time of their formation. Together with a lack of observed, coherent tracks, and conflicting geochemical arguments (e.g. [27]), we suggest that it is unlikely that the Crozet or Conrad Rise volcanism was responsible for the Rajmahal volcanism.

\section{Revised Indian Ocean plate rotations}

The absolute motion of a plate can, in theory, be defined by the rotation which reconstructs the present-day position of two points, with their known position in the past. In our case, we use the volcanic tracks left by the Kerguelen and Reunion plumes, together with their calculated position in the past, to revise the absolute motion of the Indian plate for the last $65 \mathrm{Ma}$.

The procedure is complicated, however, by uncertainties in age, the position of the hotspot relative to the volcanics at the time of eruption, calculated hotspot motion, rotation rate, and intraplate deformation. Thus, a best-fit approach is required to minimize the misfit of an estimated rotation. We use a method described in [45], which uses a least-squares approach to minimize the normalized deviations, which are defined as the deviation vectors divided by the estimated errors. We first rotated all hotspot track data into the Indian plate reference frame. The method uses a two-step approach to the minimization, in that it first calculates a preliminary solution based only on the spatial errors, initially assuming no time errors. This preliminary solution is then used to convert the time errors into spatial errors, effectively defining a spatial error ellipse for each data point in the hotspot track. A second solution is then obtained.

Table 2 presents our revised finite rotations for the Indian plate based on the calculated hotspot motion of Reunion and Kerguelen shown in Fig. 3. Fig. 6 illustrates the motion of the Indian hemisphere plates based on this absolute reference frame. Two distinct features of this model, both related to hotspot motion, are the relative rotation of India, and the longitudinal (westward) shift of India with respect to previous models using fixed African hotspots (e.g. [28]). The former is primarily related to the position of the Kerguelen plume in the past, i.e. since the plume was farther north, eastern India needs a somewhat smaller amount of motion to fit the hotspot position. Since the paleolatitude of the Kerguelen plume has been independently estimated [42,55] and shown to be consistent with this calculated motion, we suggest this feature is quite robust. The second feature arises from the calculated longitudinal (eastward) shift of the Reunion plume through time. Hence to fit the plume's paleolon- 

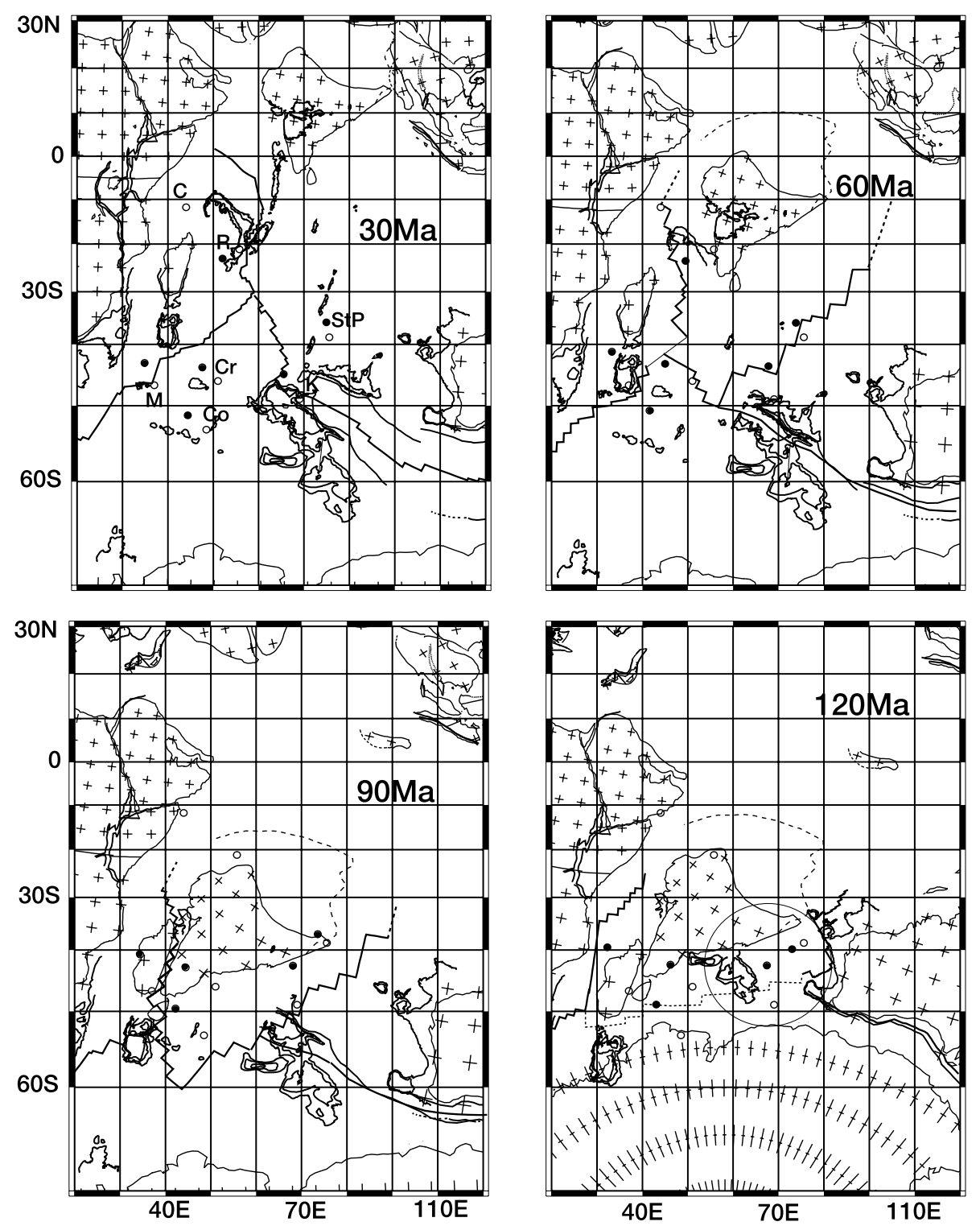

Fig. 5. Calculated positions of Indian Ocean hotspots at 30, 60, 90 and 120 Ma (filled circles). Hotspots shown are St. Paul-Amsterdam (StP), Kerguelen (K), Reunion (R), Comores (C), Crozet (Cr), Conrad Rise (Co) and Marion (M). Unfilled circles indicate the present positions of the hotspots. Plate reconstruction model in fixed hotspot reference frame; based on Gaina et al. [4]. Approximate positions of spreading centers shown as dark lines.

gitude, India had to be respectively farther west at a given time in the past. While this shift is within the longitudinal variation displayed by the Deccan Traps, it is not possible to independently constrain this feature of our model, and this may be an artifact of our calculated motion.

\section{Discussion}

One of reasons for the coherent motion of hotspots under a fast-moving plate is the mid-level mantle flow due to this motion (cf. Fig. 3). However, Africa and Antarctica have not exhibited 
Table 2

Revised finite rotations for the Indian plate based on the calculated motion of the Kerguelen and Reunion hotspots (left) and for fixed hotspots (right; format latitude, longitude, angle)

\begin{tabular}{lllrrrr}
\hline $\begin{array}{l}\text { Age } \\
\text { (Ma) }\end{array}$ & \multicolumn{1}{l}{$\lambda$} & $\phi$ & $\theta$ & \multicolumn{1}{l}{$\lambda$} & \multicolumn{1}{l}{$\phi$} & \multicolumn{1}{l}{$\theta$} \\
\hline 10.0 & -38.7 & -178.4 & 6.3 & -35.8 & -157.7 & 5.9 \\
20.0 & -37.7 & -171.9 & 12.9 & -40.6 & -175.6 & 10.6 \\
30.0 & -38.9 & -170.1 & 20.3 & -32.7 & -164.6 & 17.1 \\
40.0 & -44.8 & -179.4 & 24.8 & -31.3 & -163.1 & 22.9 \\
50.0 & -42.4 & -197.6 & 32.5 & -26.9 & -170.5 & 31.2 \\
60.0 & -35.4 & -207.1 & 43.0 & -22.9 & -175.4 & 42.5 \\
65.0 & -31.1 & -209.0 & 49.3 & 19.4 & -176.5 & 52.3 \\
\hline
\end{tabular}

Ages based on the Cande and Kent [71] timescale. Motion of hotspots found in Table $3^{1}$.

dramatic motion in the mantle reference frame for at least the last $50 \mathrm{Ma}$, and the motion of hotspots under these plates is dominated by the large-scale mantle dynamics of these regions (e.g. a lower mantle upwelling under southern Africa) rather than plate return flow. Thus the contrast in calculated motion between the Reunion and Kerguelen plumes, which is, in both cases, supported by paleomagnetic data (Fig. 4), is a natural consequence of the mantle flow field beneath the Indian Ocean.

The reason for the fact that this motion has not been required in absolute plate motion models is that there are intrinsically large uncertainties in defining a finite rotation pole for a plate relative to two hotspots. Large spatial errors are introduced by poorly known present-day positions and uncertainties in the past location of the plume relative to surface volcanism. Together with intrinsic dating errors, the real estimate of uncertainty may be quite large. In contrast to techniques in estimating uncertainties in relative plate motions [63-65], a rigorous approach for estimating uncertainties in absolute motions is lacking. One measure of assessing the validity of a model is to compare the observed and predicted hotspot tracks for a given absolute plate model. This is shown for the models discussed in this paper in Fig. 7, for the Indian plate. The filled

\footnotetext{
${ }^{1}$ For Table 3 see online version of this article.
}

triangles represent the predicted tracks of the Gaina et al. [4] plate model, assuming fixed hotspots. While the fit to the Reunion track is acceptable, there is systematic misfit of the $90^{\circ} \mathrm{E}$ Ridge, as was previously found by Müller et al. [28] and Royer et al. [11]. The filled diamonds represent our calculated tracks for moving Kerguelen and Reunion hotspots, with our revised plate model, up to $65 \mathrm{Ma}$. The fit to the observed tracks is considerably better than for fixed hotspots. The misfit between the dated Deccan Traps sample and the filled diamond at $65 \mathrm{Ma}$ reflects the large spatial extent of the Deccan Traps. A significant uncertainty exists concerning the position and track of the Kerguelen plume for times less than $20 \mathrm{Ma}$. Though it is likely to have been under the North Kerguelen Plateau, its past positions with respect to the Antarctic plate are not well-constrained.

A revision of the Indian plate rotations is limited by two factors. First, the rotations are sensitive to small artifacts, such as unconstrained longitudinal variations. This problem is in large part due to the small number of well-defined and dated hotspot tracks available in the Indian Ocean, and the rotations would certainly be improved by the inclusion of hotspots from the Atlantic Ocean. This is, however, outside the scope of the current paper.

Second, the rotations are limited by the time period for which the Reunion hotspot has existed ( $<65 \mathrm{Ma}$ ). Unfortunately, the much older Marion plume has a much less well-defined track for older times, and its position, when under Madagascar, is subject to large uncertainties. The Kerguelen plume track has been much better dated; however, it too is subject to ambiguities. A large offset in magnetic lineations, and subsequently age, exists across the Ninetyeast Ridge (e.g. [28]). This suggests that the volcanic ridge was associated with a transform fault. If this is the case, then it is possible that melt from the Kerguelen plume was advected from the sub-lithospheric plume position to the adjacent structural heterogeneity provided by the ridge. Thus the Ninetyeast Ridge may only approximate the position of the Kerguelen plume. A similar situation exists for the Rajmahal Traps, in that the depleted 

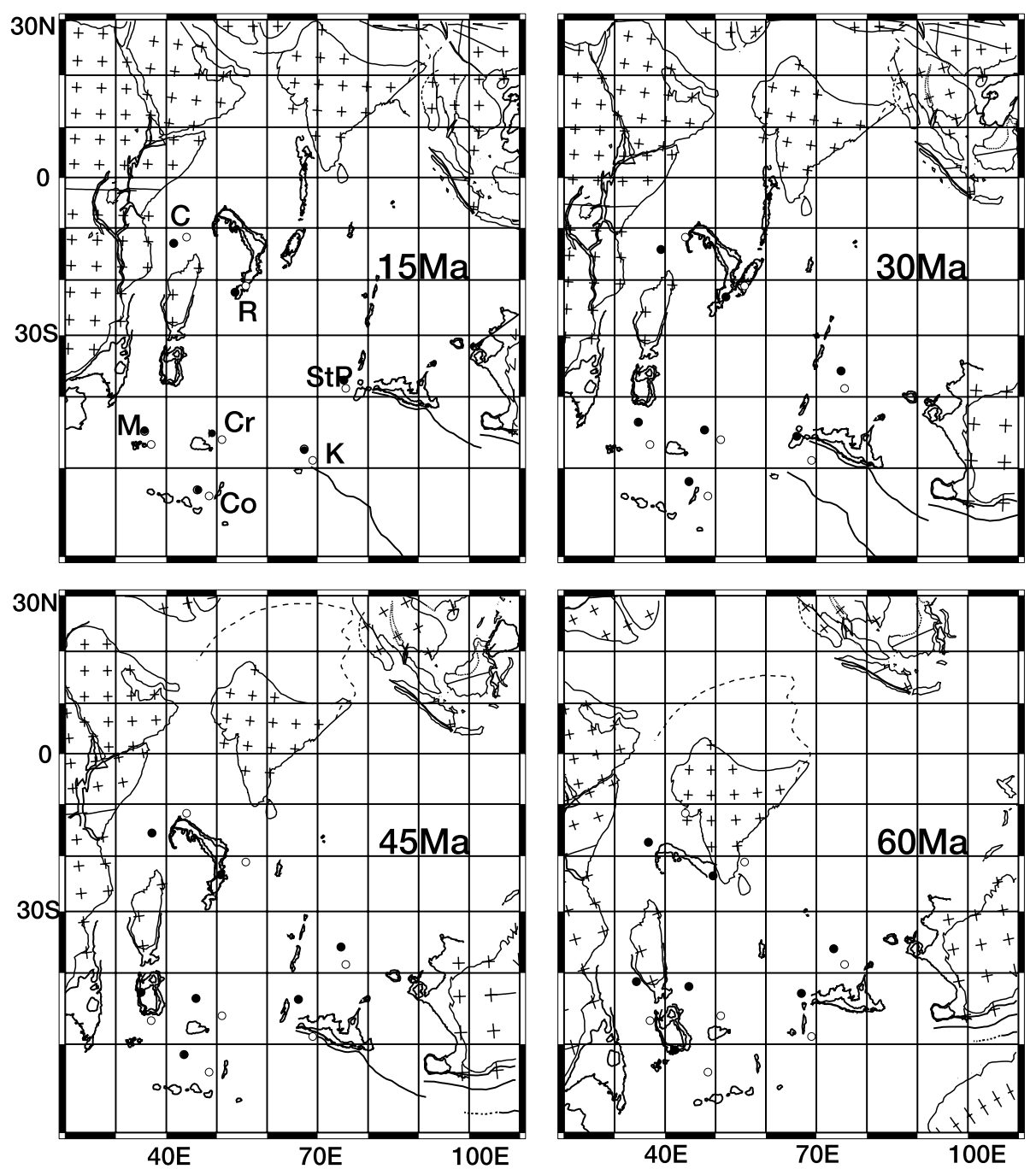

Fig. 6. Revised Indian absolute plate model for the last $65 \mathrm{Ma}$ based on moving Kerguelen and Reunion hotspots. Hotspot positions (filled circles) shown for each time. Hotspots shown are St. Paul-Amsterdam (StP), Kerguelen (K), Reunion (R), Comores (C), Crozet (Cr), Conrad Rise (Co) and Marion (M). Unfilled circles indicate the present positions of the hotspots.

signature of the basalts suggests the proximity of a spreading ridge. In this case, plume melt may have similarly been advected to the spreading center. However, an additional constraint in this case is provided by the jump of the spreading center after $124 \mathrm{Ma}$ to form the Elan Bank microcontinent, as deduced from magnetic anomalies [4]. In this case a plume almost certainly existed proximal to northeast India to cause the jump at this time; however, it was not necessarily the plume head. This casts doubt on whether the Rajmahal
Traps represent the eruption of the Kerguelen plume head. Similarly, older volcanic features such as the volcanism on the Naturaliste Plateau ( $110 \mathrm{Ma}[66])$ and the Bunbury Basalts (123$132 \mathrm{Ma}[12,33])$ in Western Australia have been ascribed to the Kerguelen plume. However, in geodynamical reconstructions these features are distal to the present position of the Kerguelen hotspot. However, if they are related to rifting initiated by the arrival of the Kerguelen plume head, then the radius of influence is significantly 
larger. Müller et al. [14] suggested that a Kerguelen plume around $10^{\circ}$ north of its present location could have been responsible for the volcanics of the Wallaby and Zenith plateaus on the Western Australian margin (between 136 and $96 \mathrm{Ma}$ ), as well as the Bunbury Basalts. However, the problem with the plume head model, as pointed out by Coffin et al. [24], is explaining how magmatic products from a single plume would erupt on the old continental lithosphere of Antarctica and
India, without voluminous magmatism in between on the young oceanic lithosphere and spreading centers of the Enderby Basin.

Coffin et al. [24] have inferred time-dependent magma output rates for the Kerguelen plume, based on volumetric estimates of the volcanic features attributed to it. This is not consistent with a simple plume head/tail model. Coffin et al. [24] suggest either multiple plumes for the Kerguelen volcanics, or that the plume conduit was sheared

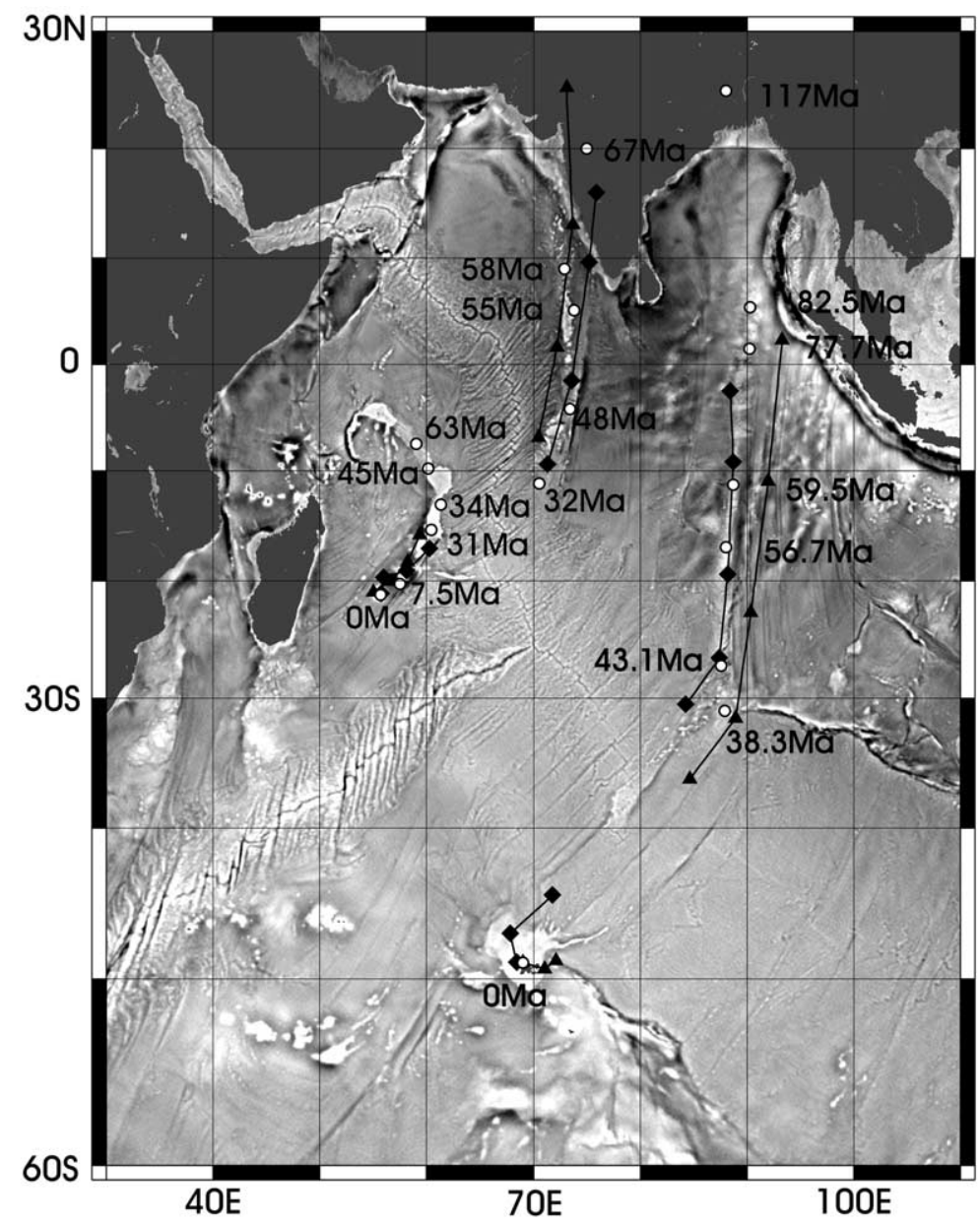

Fig. 7. Calculated tracks of the Kerguelen and Reunion hotspot. Reunion tracks are on the Indian plate for ages greater than 30 $\mathrm{Ma}$, and on the African plate for younger times. Kerguelen tracks are on the Indian plate for times greater than $20 \mathrm{Ma}$, and on the Antarctic plate for younger times. Filled triangles represent tracks for fixed hotspots and an absolute plate model based on fixed African hotspots [4]. Filled diamonds represent our revised plate model (Table 1) and moving hotspots (Fig. 3), for the last $65 \mathrm{Ma}$. Symbols represent $10 \mathrm{Myr}$ intervals, except for last symbols for moving hotspot tracks, which are at 65 Ma. Unfilled circles indicate sample locations together with their radiometrically determined ages, from ODP Legs 115 (Reunion track, holes 706, 707 and 715), industry wells (SM-1 and NB-1), ODP Legs 119, 120 (Kerguelen Plateau, holes 747-749), 121 (Ninetyeast Ridge, holes 756-758) and 183 (Kerguelen Plateau, holes 1138 and 1140) [3,15,17,42,55,70]. 
by vigorous mantle flow into several 'diapirs'. In terms of multiple plumes, the Amsterdam-St. Paul hotspot has been suggested to have contributed to the Ninetyeast Ridge; however, our calculated motion precludes its involvement in the Kerguelen-associated volcanic features. Our calculated tilt for the Kerguelen plume indicates that it should be stable. However, the large depth variations in shear flow at mid-mantle levels, caused by the initiating of rifting and dispersal of Gondwana, could have resulted in shear of the early plume. This would result in time-dependent and aerially extensive volcanism, rather than the development of a single, large LIP coinciding with the arrival of the plume head. Similarly, evidence for a pre-Deccan history of the Reunion hotspot [67] seems to conflict with a plume head model. While earlier Reunion activity may simply reflect a delay in the arrival of the plume head and the time of rifting, a model of shear of the initial conduit can also provide an explanation.

Finally, the paleolatitude estimates used to constrain the calculated motion of the hotspots could potentially be explained as the result of TPW. The observed paleolatitudes of the Reunion hotspot are consistent with some TPW curves (e.g. [59]), and predictions from hotspot motion. The combination of the two effects results in calculated paleolatitudes consistent with the uncertainties of the observations. TPW cannot explain the paleolatitudes of the Kerguelen hotspot, which are offset in the opposite direction (see Fig. 4, bottom). This was also previously found by Antretter et al. [3], who concluded that the paleolatitudes of the Kerguelen hotspot required hotspot motion. Again, the combination of TPW and hotspot motion gives paleolatitudes consistent with those observed. The apparent fixity of the Marion hotspot, based on a single paleolatitude estimate [5], is not consistent with our calculated hotspot motion. Older TPW curves alleviate this problem, since the latitudinal offsets cancel, resulting in an apparent fixity. However, the most recent TPW path of Besse and Courtillot [61] shows little paleolatitude variation of the Marion plume due to TPW. It is interesting to note that their TPW path has only 13 poles for the $90 \mathrm{Ma}$ reconstruction, two of which are from Madagascar. If we apply a more rigid selection criterion, such as a demagnetization code of three or greater (see [68]), the Madagascan poles and one Australian pole are eliminated. The resulting geomagnetic pole position at $90 \mathrm{Ma}$ is $\left(81.7^{\circ} \mathrm{N}, 293.1^{\circ} \mathrm{E}\right)$. This results in a paleolatitude for the Marion $-47.5^{\circ}$, which goes some way to providing the negative TPW latitudinal offset required. An additional factor is that since they assume fixed hotspots in the construction of this TPW path, it is not entirely surprising that the calculated paleolatitudes of the Marion hotspot based on it tend to imply little motion of the Marion hotspot. A final cautionary note is that, while Torsvik et al. [5] present a combined Madagascan pole, the paleolatitude they present is for Volcan de l'Androy $\left(24.2^{\circ} \mathrm{S}, 46^{\circ} \mathrm{E}\right)$ in southeast Madagascar. The Madagascan volcanics span $\sim 8^{\circ}$ latitude, and if we take a point $8^{\circ}$ north of Volcan de l'Androy, we obtain a paleolatitude of $37.6^{\circ} \mathrm{S}$, in perfect agreement with our calculated hotspot motion.

\section{Conclusions}

While fixed hotspots are a useful reference frame for absolute plate reconstructions, the notion of their fixity in a convecting mantle is physically implausible. The motion of these hotspots can be calculated, however, and while the results are model-dependent, the estimated motions are consistent with available geological and paleomagnetic evidence. The motion of the Indian Ocean hotspots provides explanations for many of the inconsistencies between geological relationships and plate reconstructions. The Reunion hotspot has drifted northeast since $65 \mathrm{Ma}$, and the latitudinal shift is similar to that independently estimated by paleomagnetic estimates [15]. The Kerguelen hotspot has drifted south since 120 $\mathrm{Ma}$, and this motion is consistent with paleomagnetic evidence based on recent drilling of the Kerguelen track and previous modeling $[3,42,55]$. This supports models for the formation of the Rajmahal Traps [21] and the Elan Bank [7], which require the Kerguelen hotspot farther north in the past. The apparent fixity of the Marion hotspot paleolatitudes may be due to a combination 
of southward hotspot motion, and apparent northward latitudinal shift due to TPW; however, more data are needed to constrain its evolution. The presented finite rotations for the Indian plate, based on the motion of these hotspots, are restricted by their ages, and by uncertainties in their position with respect to the observed track. However, they suggest India was farther north in the past than for fixed hotspot models.

\section{Acknowledgements}

The authors would like to thank J. Besse, R. Duncan and M. Coffin for constructive reviews, which resulted in a vastly improved manuscript, and V. Courtillot for helpful comments on the text.[ $\boldsymbol{V C}]$

\section{References}

[1] B. Steinberger, R.J. O'Connell, Effects of mantle flow on hotspot motion, in: M.A. Richards, R.G. Gordon, R.D. van der Hilst (Eds.), The History and Dynamics of Global Plate Motions, AGU, Washington, DC, 2000, pp. 377398.

[2] B. Steinberger, R.J. O'Connell, Advection of plumes in mantle flow: implications for hotspot motion, mantle viscosity and plume distribution, Geophys. J. Int. 132 (1998) 412-434.

[3] M. Antretter, B. Steinberger, F. Heider, H. Soffel, Paleolatitudes of the Kerguelen hotspot: new paleomagnetic results and dynamic modeling, Earth Planet. Sci. Lett. 203 (2002) 635-650.

[4] C. Gaina, R.D. Müller, B. Brown, T. Ishihara, Microcontinent formation around Australia, in: R. Hillis, R.D. Müller (Eds.), The Evolution and Dynamics of the Australian Plate, Geol. Soc. Aust. Spec. Publ. 22 and Geol. Soc. Am. Spec. Paper 372 (2003) 399-410.

[5] T.H. Torsvik, R.D. Tucker, L.D. Ashwal, E.A. Eide, N.A. Rakotosolofo, M.J. de Wit, Late Cretaceous magmatism in Madagascar: palaeomagnetic evidence for a stationary Marion hotspot, Earth Planet. Sci. Lett. 164 (1998) 221-232.

[6] R.A. Duncan, Age distribution of volcanism along aseismic ridges in the eastern Indian Ocean, in: J. Weissel, J. Peirce, E. Taylor, J. Alt, et al. (Eds.), Proc. ODP Sci. Results 121 (1991) 507-517.

[7] W.J. Morgan, Hotspot tracks and the opening of the Atlantic and Indian Oceans, in: C. Emiliani (Ed.), The Oceanic Lithosphere, The Sea 7, Wiley, New York, 1981, pp. 443-487.
[8] D. Weis, S. Ingle, D. Damasceno, F.A. Frey, K.E. Nicolaysen, J. Barling, Origin of continental components in Indian Ocean basalts: Evidence from Elan Bank (Kerguelen Plateau, ODP Leg 183, site 1137), Geology 29 (2001) 147-150.

[9] J.J. Mahoney, J.D. Macdougall, G.W. Lugmair, K. Gopalan, Kerguelen hot spot source for the Rajmahal Traps and Ninetyeast Ridge?, Nature 303 (1983) 385-389.

[10] F.A. Frey, M.F. Coffin, P.J. Wallace, D. Weis, X. Zhao, S.W. Wise, V. Wahnert, D.A.H. Teagle, P.J. Saccocia, D.N. Reusch, M.S. Pringle, K.E. Nicolaysen, C.R. Neal, R.D. Muller, C.L. Moore, J.J. Mahoney, L. Keszthelyi, H. Inokuchi, R.A. Duncan, H. Delius, J.E. Damuth, D. Damasceno, H.K. Coxall, M.K. Borre, F. Boehm et al., Origin and evolution of a submarine large igneous province: the Kerguelen Plateau and Broken Ridge, southern Indian Ocean, Earth Planet. Sci. Lett. 176 (2000) 73-89.

[11] J.-Y. Royer, J.W. Pierce, J.K. Weissel, Tectonic constraints on hotspot formation of the Ninetyeast Ridge, ODP Init. Reports (1991) 121-122.

[12] S. Ingle, D. Weis, J.S. Scoates, F.A. Frey, Relationship between the early Kerguelen plume and continental flood basalts of the paleo-Eastern Gondwanan margins, Earth Planet. Sci. Lett. 197 (2002) 35-50.

13 M. Storey, R.W. Kent, A.D. Saunders, V.J.M. Salters, J. Hergt, H. Whitechurch, H.J. Sevigny, M.F. Thirlwall, P. Leat, N.C. Chose, M. Gifford, Lower Cretaceous volcanic rocks on continental margins and their relationships to the Kerguelen Plateau, Proc. ODP Sci. Results 120 (1992) 3353.

[14] R.D. Müller, D. Mihut, C. Heine, C. O’Neill, I. Russell, Tectonic and volcanic history of the Carnarvon Terrace: Constraints from seismic interpretation and geodynamical modelling, in: M. Keep, S.J. Moss (Eds.), Proceedings of the Western Australian Basins Symposium (WABS III), vol. 3, Oilfield Publications, Perth, 2002, pp. 719-740.

[15] D. Vandamme, V. Courtillot, Paleomagnetism of Leg 115 basement rocks and latitudinal evolution of the Reunion hotspot, in: R.A. Duncan, J. Backman, R.B. Dunbar, L.C. Peterson (Eds.), Proc. ODP Sci. Results 115 (1990) 111-118.

[16] J.Y. Royer, J.G. Sclater, D.T. Sandwell, S.C. Cande, R. Schlich, M. Munschy, J. Dyment, R.L. Fisher, R.D. Müller, M.F. Coffin, P. Patriat, H.W. Bergh, Indian Ocean plate reconstructions since the Late Jurassic, in: R.A. Duncan, D.K. Rea, R.B. Kidd, U. v. Rad, J.K. Weissel (Eds.), Synthesis of Results from Scientific Drilling in the Indian Ocean, Geophys. Monogr. 70, AGU, Washington, DC, 1992, pp. 471-475.

[17] R.A. Duncan, The volcanic record of the Reunion hotspot, in: R.A. Duncan, J. Backman, R.B. Dunbar, L.C. Peterson (Eds.), Proc. ODP Sci. Results 115 (1990) 3-10.

[18] V.E. Courtillot, J. Besse, D. Vandamme, R. Montigny, J. Jaeger, H. Cappetta, Deccan flood basalts at the Cretaceous/Tertiary boundary?, Earth Planet. Sci. Lett. 80 (1986) 361-374. 
[19] M. Storey, J.J. Mahoney, A.D. Saunders, R.A. Duncan, S.P. Kelley, M.F. Coffin, Timing of hot spot-related volcanism and the breakup of Madagascar and India, Science 267 (1995) 852-855.

[20] J. Mahoney, C. Nicollet, C. Dupuy, Madagascar basalts tracking oceanic and continental sources, Earth Planet. Sci. Lett. 104 (1991) 350-363.

[21] J.E. Georgen, J. Lin, H.J.B. Dick, Evidence from gravity anomalies for interactions of the Marion and Bouvet hotspots with the Southwest Indian Ridge; effects of transform offsets, Earth Planet. Sci. Lett. 187 (2001) 283-300.

[22] J. Barling, Heard and McDonald Islands, in: W.E. LeMasurier, J.W. Thomson (Eds.), Volcanoes of the Antarctic Plate and Southern Ocean, Antarctic Research Series 48, AGU, Washington, DC, 1990, pp. 435-441.

[23] R.A. Duncan, A time frame for construction of the Kerguelen Plateau and Broken Ridge, J. Petrol. 43 (2002) 1109-1119.

[24] M.F. Coffin, M.S. Pringle, R.A. Duncan, T.P. Gladczenko, M. Storey, R.D. Mueller, L.A. Gahagan, Kerguelen hotspot magma output since 130 Ma, J. Petrol. 43 (2002) $1121-1139$.

[25] R.E. Houtz, D.E. Hayes, R.G. Markl, Kerguelen Plateau bathymetry, sediment distribution, and crustal structure, Mar. Geol. 25 (1977) 95-130.

[26] R.D. Müller, W.R. Roest, J.-Y. Royer, L.M. Gahagan, J.G. Sclater, Digital isochrons of the world's ocean floor, J. Geophys. Res. 102 (1997) 3211-3214.

[27] W. Kent, A.D. Saunders, P.D. Kempton, N.C. Ghose, Rajmahal basalts, eastern India: Mantle sources and melt distribution at a volcanic rifted margin, in: J.J. Mahoney, M.F. Coffin (Eds.), Large Igneous Provinces: Continental, Oceanic, and Planetary Flood Volcanism, Geophys. Monogr. 100, AGU, Washington, DC, 1997, pp. 145-182.

[28] R.D. Müller, J.-Y. Royer, L.A. Lawver, Revised plate motions relative to the hotspots from combined Atlantic and Indian Ocean hotspot tracks, Geology 16 (1993) 275278.

[29] J.R. Curray, T. Munasinghe, Origin of the Rajmahal Traps and the $85^{\circ} \mathrm{E}$ Ridge preliminary reconstructions of the trace of the Crozet hotspot, Geology 19 (1991) 1237-1240.

[30] A.K. Baksi, T.R. Barman, D.K. Paul, E. Farrar, Widespread Early Cretaceous flood basalt volcanism in Eastern India: geochemical data from the Rajmahal-Bengal-Sylhet Traps, Chem. Geol. 63 (1987) 133-141.

[31] R.W. Kent, M.S. Pringle, R.D. Mueller, A.D. Saunders, N.C. Ghose, 40Ar/39Ar Geochronology of the Rahmahal Basalts, India, and their relationship to the Kerguelen Plateau, J. Petrol. 43 (2002) 1141-1153.

[32] O. Eldholm, M.F. Coffin, Large igneous provinces and plate tectonics, in: M.A. Richards, R.G. Gordon, R.D. van der Hilst (Eds.), The History and Dynamics of Global Plate Motions, Geophys. Monogr. 121, AGU, Washington, DC, 2000, pp. 309-326.

[33] F.A. Frey, N.J. McNaughton, D.R. Nelson, J.R. Dela- eter, R.A. Duncan, Petrogenesis of the Bunbury basalt, western Australia: Interaction between the Kerguelen plume and Gondwana lithosphere?, Earth Planet. Sci. Lett. 144 (1996) 163-183.

[34] C. Class, S.L. Goldstein, Plume-lithosphere interactions in the ocean basins: constraints from the source mineralogy, Earth Planet. Sci. Lett. 150 (1997) 245-260.

[35] C.M. Emerick, R.A. Duncan, Age progressive volcanism in the Comores Archipelago, western Indian Ocean and implications for Somali plate tectonics, Earth Planet. Sci. Lett. 62 (1982) 439.

[36] K.T.M. Johnson, D.W. Graham, K.H. Rubin, K. Nicolaysen, D.S. Scheirer, D.W. Forsyth, E.T. Baker, L.M. Douglas-Priebe, Boomerang Seamount: the active expression of the Amsterdam-St. Paul hotspot, Southeast Indian Ridge, Earth Planet. Sci. Lett. 183 (2000) 245-259.

[37] D.W. Graham, K.T.M. Johnson, L.D. Priebe, J.E. Lupton, Hotspot-ridge interaction along the Southeast Indian Ridge near Amsterdam and St. Paul islands: helium isotope evidence, Earth Planet. Sci. Lett. 167 (1999) 297 310 .

[38] R.A. Duncan, R.B. Hargraves, ${ }^{40} \mathrm{Ar} /{ }^{39} \mathrm{Ar}$ geochronology of basement rocks from the Mascarene Plateau, the Chagos Bank, and the Maldives Ridge, in: R.A. Duncan, J. Backman, R.B. Dunbar, L.C. Peterson (Eds.), Proc. ODP Sci. Results 115 (1990) 43-52.

[39] C. Hofmann, G. Feraud, V. Courtillot, ${ }^{40} \mathrm{Ar} /{ }^{39} \mathrm{Ar}$ dating of minerals separates and whole rocks from the Western Ghats lava pile: further constraints on the duration and age of the Deccan Traps, Earth Planet. Sci. Lett. 180 (2000) 13-27.

[40] D. Vandamme, V. Courtillot, J. Besse, Paleomagnetism and age determinations of the Deccan Traps (India): Results of a Nagpur-Bombay tranverse and review of earlier work, Rev. Geophys. 29 (1991) 159-190.

[41] H. Whitechurch, R. Montigny, J. Sevigny, M. Storey, V. Salters, K-Ar and ${ }^{40} \mathrm{Ar}-{ }^{39} \mathrm{Ar}$ ages of central Kerguelen Plateau basalts, in: S.W. Wise, Jr., R. Schlich, et al. (Eds.), Proc. ODP Sci. Results 120 (1992) 71-77.

[42] H. Inokuchi, F. Heider, Paleolatitude of the Southern Kerguelen Plateau inferred from the paleomagnetic study of Late Cretaceous basalts, in: J.S.W. Wise, A.P. Julson, R. Schlich, E. Thomas (Eds.), Proc. ODP Sci. Results 120 (1992) 89-98.

[43] C.T. Klootwijk, S.G. Jeff, J.W. Peirce, G.M. Smith, Constraints on the India-Asia convergence: Paleomagnetic results from Ninetyeast Ridge, in: J.K. Weissel, J.W. Peirce, E. Taylor, J. Alt (Eds.), Proc. ODP Sci. Results 121 (1991).

[44] C.T. Klootwijk, Paleomagnetism of the Upper Gondwana Rajmahal Traps, northeast India, Tectonophysics 12 (1971) 449-467.

[45] B. Steinberger, Plumes in a convecting mantle: Models and observations for individual hotspots, J. Geophys. Res. 105 (2000) 11127-11152.

[46] B.H. Hager, R.J. O'Connell, Kinematic models of large scale mantle flow, J. Geophys. Res. 84 (1979) 1031-1048. 
[47] B.H. Hager, R.J. O'Connell, A simple global model of plate dynamics and mantle convection, J. Geophys. Res. 86 (1981) 4843-4867.

[48] S.P. Grand, R.D. van der Hilst, S. Widiyantoro, Global seismic tomography: A snapshot of convection in the Earth, GSA Today 7 (1997) 1-7.

[49] W.J. Su, R.L. Woodward, A.M. Dziewonski, Degree 12 model of shear velocity heterogeneity in the mantle, J. Geophys. Res. 99 (1994) 6945-6980.

[50] M.A. Richards, R.A. Duncan, V.E. Courtillot, Flood basalts and hot spot tracks plume heads and tails, Science 246 (1989) 103-107.

[51] V. Courtillot, A. Davaille, J. Besse, J. Stock, Three distinct types of hotspots in the Earth's mantle, Earth Planet. Sci. Lett. 205 (2003) 295-308.

[52] R.C. Gordon, D.M. Jurdy, Cenozoic global plate motions, J. Geophys. Res. 91 (1986) 12389-12406.

[53] C. Lithgow-Bertelloni, M.A. Richards, The dynamics of Cenozoic and Mesozoic plate motions [Review], Rev. Geophys. 36 (1998) 27-78.

[54] B. Steinberger, Motion of the Easter hot spot relative to the Hawaii and Louisville hot spot, Geochem. Geophys. Geosyst. 3 (2002) doi:10.1029/2002GC000334.

[55] M. Antretter, B. Steinberger, F. Heider, H. Soffel, A stationary hotspot or hotspot motion? - A contribution from the Kerguelen Plateau, in: EGS Annual Conference, Nice, 2000.

[56] J.A. Whitehead, Instabilities of fluid conduits in a flowing Earth - are plates lubricated by an asthenosphere?, Geophys. J. R. Astron. Soc. 70 (1982) 415-433.

[57] I.O. Norton, Global hotspot reference frames and plate motion, in: M.A. Richards, R.G. Gordon, R.D. van der Hilst (Eds.), The History and Dynamics of Global Plate Motions, AGU, Washington, DC, 2000, pp. 339358.

[58] R.A. Duncan, M.A. Richards, Hotspots, mantle plumes, flood basalts, and true polar wander, Rev. Geophys. 29 (1991) 31-50.

[59] J. Besse, V. Courtillot, Revised and synthetic apparent polar wander paths of the African, Eurasian, North American and Indian Plates and true polar wander since 200 Ma, J. Geophys. Res. 96 (1991) 4029-4050.

[60] M. Prevot, E. Mattern, P. Camps, M. Daignieres, Evidence for a 20 degree tilting of the Earth's rotation axis
110 million years ago, Earth Planet. Sci. Lett. 179 (2000) 517-528.

[61] J. Besse, V. Courtillot, Apparent and true polar wander and the geometry of the geomagnetic field over the last 200 Myr, J. Geophys. Res. 107(B11) (2002) doi:1029/ 2000JB000050.

[62] M.C. Van Fossen, D.V. Kent, Paleomagnetism of $122 \mathrm{Ma}$ plutons in New England and the Mid-Cretaceous paleomagnetic field in North America: True polar wander or large-scale differential mantle motion?, J. Geophys. Res. 97 (1992) 19651-19661.

[63] T. Chang, On the statistical properties of estimated rotations, J. Geophys. Res. 92 (1987) 6319-6329.

[64] T. Chang, Estimating the relative rotation of two tectonic plates from boundary crossings, J. Am. Stat. Assoc. 83 (1988) 1178-1183.

[65] T. Chang, J. Stock, P. Molnar, The rotation group in plate tectonics and the representation of uncertainties of plate reconstructions, Geophys. J. Int. 102 (1992) 649661.

[66] J.J. Mahoney, W.B. Jones, F.A. Frey, V.J.M. Salters, D.G. Pyle, H.L. Davies, Geochemical characteristics of lavas from Broken Ridge, the Naturaliste Plateau and southernmost Kerguelen Plateau: Cretaceous plateau volcanism in the southeast Indian Ocean, Chem. Geol. 120 (1995) 315-345.

[67] J.J. Mahoney, R.A. Duncan, G.R. McCormick, E. Gnos, W. Khan, Cretaceous volcanic rocks of the South Tethyan suture zone, Pakistan: Implications for the Reunion Hotspot and Deccan Traps, Earth Planet. Sci. Lett. 203 (2002) 295-310.

[68] M.W. McElhinny, P.L. McFadden, Palomagnetism: Continents and Oceans, Academic Press, San Diego, CA, 1999, 386 pp.

[69] D.T. Sandwell, W.H.F. Smith, Marine gravity anomaly from Geosat and ERS-1 satellite altimetry, J. Geophys. Res. 102 (1997) 10039-10054.

[70] R. Schlich, S.W.J. Wise, The geologic and tectonic evolution of the Kerguelen Plateau: an introduction to the scientific results of Leg 120, in: S.W.J. Wise, R. Schlich, et al. (Eds.), Proc. ODP Sci. Results 120 (1992) 5-30.

[71] S.C. Cande, D.V. Kent, Revised calibration of the geomagnetic polarity timescale for the Late Cretaceous and Cenozoic, J. Geophys. Res. 100 (1995) 6093-6095. 